\title{
Evaluasi Variabilitas Kinerja Struktur Perkerasan Jalan Berbasis Pengujian Seismik
}

(Evaluation on Pavement Structural Performance Variability Based on Seismic Testing)

\author{
SRI ATMAJA P. ROSYIDI
}

\begin{abstract}
ABSTRAK
Evaluasi perkerasan jalan diperlukan untuk memeriksa kerusakan awal yang terjadi pada perkerasan. Penilaian perkerasan dilakukan untuk memprediksi kualitas material perkerasan secara fungsional dan struktural. Penelitian ini bertujuan untuk menilai dan mengevaluasi perkerasan jalan secara struktural menggunakan pengukuran seismik Spectral Analysis of Surface Waves (SASW). Metode SASW menguji sifat material perkerasan sebagai teknik evaluasi struktural. Metode SASW merupakan metode seismik non-destruktif yang menghasilkan, mengukur, dan memproses gelombang Rayleigh yang terdispersi. Selanjutnya, proses inversi dengan teknik optimasi digunakan untuk menganalisis data dispersi gelombang Rayleigh guna menghasilkan profil kekakuan setempat, dalam parameter kecepatan gelombang geser dan modulus elastisitas. Parameter kekakuan dari metode ini yang dihasilkan pada tingkat regangan mikroskopis yaitu kurang dari $0,001 \%$, di mana pada tingkat ini, bahan tanah berperilaku elastis linier. Hasil dari uji SASW selanjutnya dibandingkan dengan uji Marshall dan nilai uji Dynamic Cone Penetrometer (DCP). Pengamatan visual juga dilakukan untuk menentukan penilaian fungsional untuk mengukur seberapa besar kerusakan permukaan jalan. Hasil penelitian menunjukkan bahwa metode SASW dapat secara efektif mengukur kecepatan gelombang geser dan variabilitas modulus elastisitas pada setiap lapisan perkerasan. Studi ini merekomendasikan pengujian seismik untuk memeriksa variabilitas kinerja struktural perkerasan jalan terpasang.
\end{abstract}

Kata kunci: Variabilitas, Kinerja Struktural, Perkerasan Jalan, Pengujian Seismik.

\section{ABSTRACT}

Evaluation of road pavement is needed to determine the early damage that occurs on the pavement. The pavement assessment predicts functionally and structurally the pavement material quality. This research aims to assess and evaluate the road pavement structurally using seismic measurement of the Spectral Analysis of Surface Waves (SASW). The SASW tests pavement's material properties as the structural evaluation technique. The SASW is a non-destructive seismic method that generates, measures, and processes the dispersed Rayleigh waves. Subsequently, an inversion process with optimization technique analyses the Rayleigh waves dispersive data to produce the stiffness profile of the site, i.e., the shear wave velocity and its corresponding elastic modulus. These generated stiffness parameters are measured at a microscopic strain level of less than $0.001 \%$, where at this level, the soil material behaves the elastic linear. Results from the SASW test were compared with the Marshall test and the Dynamic Cone Penetrometer (DCP) test value. Visual observation determines the functional assessment to measure how much damage to the road surface. The results show that the SASW method can effectively measure shear wave velocity and elastic modulus variability in each pavement layer. This study recommends seismic testing for determining the variability of the structural performance of the existing road pavements.

Keywords: Variability, Structural Performance, Pavement, Seismic Testing. 


\section{PENDAHULUAN}

Perkerasan merupakan sebuah sistem yang kompleks dimana sistem manajemen perkerasan digunakan untuk menjamin tingkat layanan jalan yang baik (Carvalho \& Santos, 2019) dan untuk memaksimalkan manfaat yang diperoleh dari perkerasan jalan (Babashamsi, dkk. 2016). Selain masalah teknis, permasalahan perkerasan jalan juga dikaitkan dengan faktor ekonomi yang diterjemahkan dalam tingkat efisiensi pemeliharaan jalan dan pengelolaan prioritas penanganan dan anggarannya. Oleh karena itu, Sistem Manajemen Perkerasan (PMS) diperlukan metode yang tepat untuk menyusun program pemeliharaan jalan yang berkelanjutan. PMS sebagai sistem pendukung keputusan yang terkait dengan strategi pengelolaan yang berkelanjutan secara teknis dan ekonomis, juga digunakan untuk menjaga kondisi optimal perkerasan jalan sesuai dengan ketentuan dan peraturan yang berlaku pada jangka waktu tertentu (Di Mascio \& Moretti, 2019). Sistem ini terdiri dari prosedur objektif dan sistematis diantaranya inventarisasi perkerasan yang ada (yaitu pengumpulan dan penyimpanan data geometris, teknis, dan mekanis); pemantauan kinerja mereka, perencanaan dan penjadwalan kegiatan pemeliharaan dan rehabilitasi; evaluasi efektivitas dan biaya kegiatan pemeliharaan yang akan dilakukan serta yang dilakukan di masa lalu (Vancura, 2013).

Terdapat dua tingkat manajemen perkerasan dalam sistem PMS, yang penting adalah pengelolaan yaitu berdasarkan tingkat jaringan jalan (Di Mascio \& Moretti, 2019) dimana keseluruhan jaringan perkerasan dipertimbangkan, dengan tujuan penilaian kondisi saat ini dengan indeks khusus rata-rata; prediksi nilai kekuatannya dengan menggunakan metode matematika untuk periode waktu yang pendek maupun panjang; identifikasi unsur-unsur yang memerlukan pemeliharaan dan/atau rehabilitasi. Tingkatan lainnya adalah berdasarkan proyek yaitu bagian perkerasan tertentu, di antara yang diidentifikasi dalam manajemen jaringan yang membutuhkan intervensi, dipertimbangkan dan keputusannya menyangkut: perbandingan teknis-ekonomi antara intervensi pemeliharaan atau rehabilitasi (misalnya analisis biaya/manfaat) selama masa pakai; prioritas strategi pemeliharaan; dan identifikasi pekerjaan pemeliharaan atau rehabilitasi khusus, serta bahan dan metodenya.

Dalam prakteknya, identifikasi perkerasan memerlukan peralatan evaluasi yang mampu mendeteksi kerusakan-kerusakan dini yang terjadi. Evaluasi penilaian ini untuk mengetahui kemampuan struktural, penyebab terjadinya kerusakan jalan dan prediksi kinerja perkerasan jalan yang dimaksud. Beberapa metode pengujian yang tanpa merusak (non-destructive testing, NDT) sudah dilakukan kajian, pengambangan teknologi dan implementasinya untuk digunakan sebagai alat ukur struktur perkerasan jalan. Salah satu metode NDT telah dimulai aplikasinya dengan menggunakan gelombang seismik permukaan sejak tahun 1958 untuk investigasi geoteknik. Selanjutnya, dalam 30 tahun berikutnya, berkembang oleh Nazarian \& Stokoe (1984) menjadi teknik analisis spektrum gelombang permukaan atau Spectral Analysis of Surface Wave (SASW). Teknik ini dirancang untuk menganalisis spektrum dari sifat penyebaran gelombang Rayleigh. Hasil dari analisis SASW dipergunakan untuk mendapatkan profil perkerasan di setiap lapisannya termasuk didalamnya sifat kekakuannya yang direpresentasikan dalam modulus elastisitas (Rosyidi \& Yusoff, 2018).

Di Indonesia, metode SASW dapat dikatakan sebagai teknik pengukuran jalan yang masih relatif baru diperkenalkan (Rosyidi \& Yusoff, 2018; Rosyidi, dkk. 2021). Dalam studi ini, variabilitas kinerja nilai struktural perkerasan jalan diukur menggunakan teknik pengukuran seismik atau teknik SASW yang dinyatakan dalam kecepatan gelombang geser dan modulus elastisitas pada setiap lapisan perkerasan lentur. Untuk mengevaluasi hasil yang diperoleh dari pengukuran SASW, dilakukan perbandingan dengan dynamic cone penetrometer (DCP) dan pengujian Marshall. Lokasi yang dipilih dalam evaluasi perkerasan ini adalah perkerasan jalan terpasang yang memiliki tingkat kerusakan tinggi yang ditentukan berdasarkan kinerja fungsional menggunakan standar ASTM D 
6433-07 dengan evaluasi visual dan penentuan nilai Pavement Condition Index (PCI).

\section{METODE PENELITIAN}

Penelitian yang dilakukan merupakan penelitian empirik yang melibatkan pengujian di lapangan dan laboratorium. Pengujian di lapangan meliputi pengujian SASW dan DCP, sedangkan di pengujian laboratorium meliputi pengujian Marshall untuk sampel lapangan yang diambil.

Dalam penelitian ini, lokasi pengujian lapangan dilaksanakan di Kecamatan Tawangsari, Kabupaten Sukoharjo, pada jalur alternatif Jalan Langkap - Tengklik dengan panjang 3,65 $\mathrm{km}$, sebagaimana dijelaskan dalam Gambar 1 . Ruas jalan terdiri dari jalan satu jalur dan dua lajur dengan lebar jalan empat (4) meter

\section{Tahapan Persiapan}

Dalam tahapan persiapan, seluruh peralatan yang digunakan dalam penelitian harus disiapkan dengan baik dan dikalibrasi supaya pengambilan dapat dilaksanakan dengan baik dan menghasilkan data yang akurat. Peralatan yang memerlukan kalibrasi adalah alat penganalisis spektrum dan sensor gelombang untuk pengujian SASW dan kalibrasi sel beban untuk alat uji Marshall.

Setelah dilakukan kalibrasi dilanjutkan dengan studi percobaan (pilot study). Percobaan ini dilakukan di Laboratorium Bahan Perkerasan Jalan Universitas Muhammadiyah Yogyakarta dengan mengambil beberapa sampel pengujian.

\section{Tahapan Pengujian}

\section{Pengujian Visual PCI}

Pengujian evaluasi visual untuk mendapatkan parameter Pavement Condition Index (PCI) dilaksanakan pada lokasi penelitian dengan mengambil segmen pengamatan dalam 20 sampel segmen penelitian. Survei pertama kali dimulai dari bagian utara jalan dari STA terkecil menuju STA terbesar. Selanjutnya setiap segmen dilakukan analisis menurut jenis kerusakannya yang kemudian ditentukan nilai menggunakan indeks kondisi perkerasan atau Pavement Condition Index (PCI).

Tahapan analisis yang harus dilakukan dalam menetapkan nilai PCI terdiri dari beberapa langkah antara lain menentukan jenis dan besaran (ukuran) kerusakan, menetapkan deduct value, menentukan nilai batas dari deduct (m), menentukan Corrected Deduct Value (CDV) maksimum dan terakhir, menghitung nilai PCI.

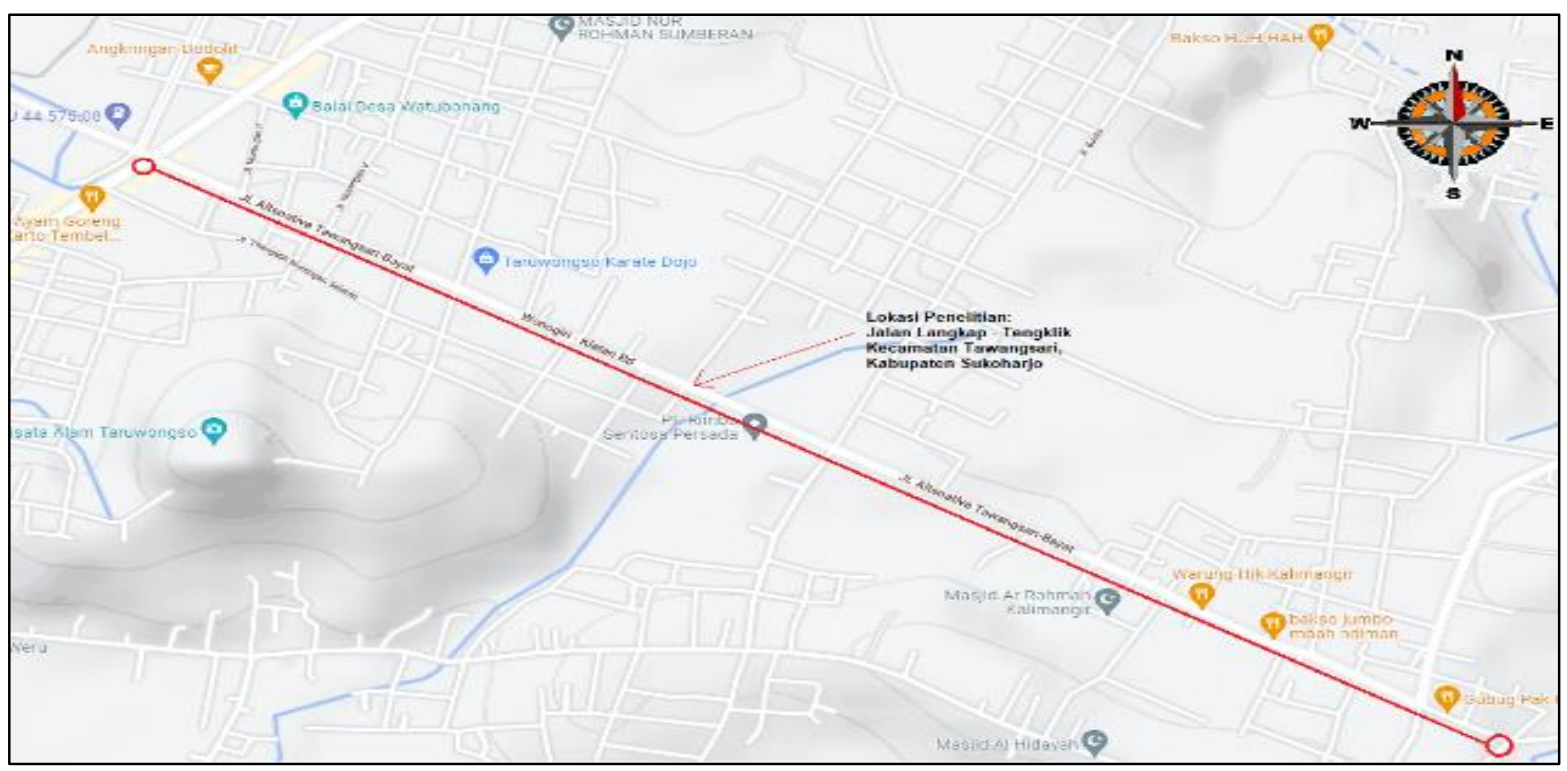

GAmbar 1. Peta Lokasi Penelitian di Jalan Langkap, Tengklik, Tawangsari, Kabupaten Sukoharjo (Sumber: Pengolahan Data Google Maps) 


\section{Pengujian DCP}

Pemeriksaan perkerasan jalan dengan alat uji Dynamic Cone Penetrometer (DCP) dilaksanakan untuk mendapatkan nilai indeks penetrasi kerucut dinamik (DCPI, dynamic cone penetrometer index) dan menggunakan nilai indeks DCP dapat dikorelasikan untuk mendapatkan daya dukung tanah dasar dalam California Bearing Ratio atau CBR dan prediksi empirik modulus elastisitas di lokasi penelitian. Peralatan DCP meliputi pemberat 8 $\mathrm{kg}$ yang diletakkan pada batang baja dengan diameter $(\mathrm{d})=1,6 \mathrm{~cm}$; dengan ketinggian sekitar $50 \mathrm{~cm}$. Pemberat digunakan sebagai penumbuk yang dijatuhkan dari $46 \mathrm{~cm}$. Nilai indeks DCP diukur dari turunnya batang baja yang ujungnya dipasang kerucut baja keras dengan sudut $60^{\circ}$. Indeks DCP merupakan nilai yang dinyatakan dari selisih penetrasi dibagi dengan selisih tumbukannya dalam unit $\mathrm{mm} /$ tumbukan untuk lapisan yang relatif seragam. Titik pengujian DCP dilakukan sama dengan titik pengujian SASW yaitu setiap jarak $50 \mathrm{~m}$. Prosedur pengujian DCP mengikuti dari standar pengujian Kementerian Pekerjaan Umum Indonesia. Besarnya nilai CBR untuk tanah dasar ditentukan berdasarkan persamaan berikut ini:

$\log _{10}$ CBR $=2,8135-1,313 \log _{10}$ DCP

Persamaan ini digunakan untuk DCP dengan konus $60^{\circ}$ yang diterapkan pada pengukuran tanah butir halus.

\section{Pengujian Marshall}

Kriteria pengujian Marshall merupakan kriteria teknis yang digunakan dalam desain dan evaluasi kinerja campuran aspal panas (hotmix). Kriteria dan prosedur pengujian Marshall merujuk pada AASHTO T 245-74 atau menggunakan SNI 06-2489-1991. Pengujian Marshall menghasilkan dua kriteria utama yaitu stabilitas dan kelelehan (flow). Sampel uji Marshall diperoleh dari lapangan dengan menggunakan alat core drill.

\section{Pengujian SASW}

Metode Spectral Analysis of Surface Wave (SASW) menggunakan peralatan sumber mekanik gelombang yang dapat menyalurkan energi seismik dari perambatan gelombang permukaan Rayleigh dengan spektrum frekuensi yang luas. Untuk itu, penggunaan sumber gelombang perlu ditentukan dan dipilih dengan tepat supaya dapat menghasilkan gelombang seismik dengan nilai frekuensi yang diharapkan. Sumber gelombang yang praktis digunakan dalam teknik SASW diantaranya sumber transien yang berasal dari pukulan atau tumbukan palu atau bola baja hingga menggunakan palu besar dan bahkan menggunakan pemberat yang dijatuhkan (dropped weight).

Gelombang seismik berfrekuensi tinggi dihasilkan dari bola baja yang dijatuhkan dan untuk menghasilkan gelombang berfrekuensi yang lebih rendah digunakan palu hingga pemberat yang dijatuhkan. Meskipun demikian, dari hasil kajian Rosyidi (2004) ditunjukkan bahwa penggunaan sumber gelombang yang sama tidak selalu menghasilkan frekuensi yang sama pada semua lokasi. Perbedaan ini dipengaruhi oleh jenis bahan, diameter/dimensi dan berat sumber gelombang yang digunakan. Dengan demikian beberapa percobaan pukulan untuk jenis dan berat sumber gelombang perlu dilakukan terlebih dahulu.

Selain sumber gelombang, dalam pengukuran SASW digunakan sensor. Jenis sensor akselerometer piezoelektrik dengan kemampuan menangkap getaran dari frekuensi rendah $10 \mathrm{~Hz}$ hingga frekuensi tinggi $(20 \mathrm{kHz})$ dipilih dalam pengujian ini. Wilayah frekuensi ini boleh digunakan untuk mendeteksi profil perkerasan hingga lapisan tanah dasar. Sensor akselerometer piezoelektrik dengan kapasitas maksimum frekuensi respon hingga $20 \mathrm{kHz} \pm 5$ $\%$ yang dihubungkan penganalisis spektrum dipergunakan untuk menerima gelombang seismik analog yang secara automatik disalurkan berbentuk digital dan ditampilkan dalam spektrum berbasis Fast Fourier Transform atau FFT (Gambar 2). 

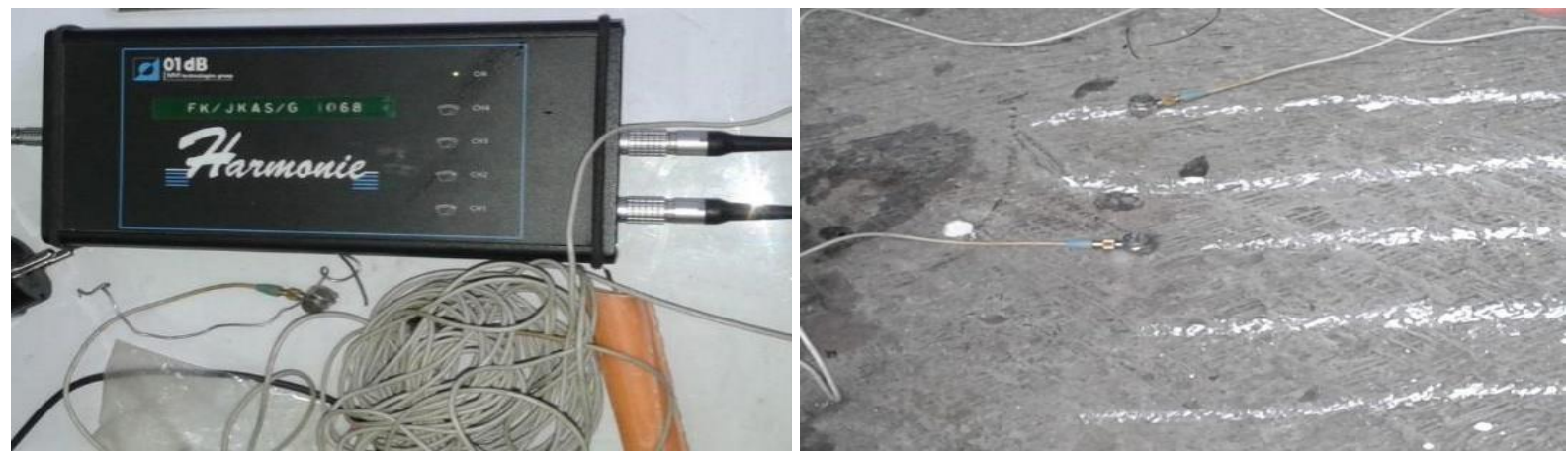

GAMBAR 2. Unit Akuisisi Harmonie 01dB dan Perangkat Sensor Akselerometer

Penganalisis spektrum dilengkapi dengan alat akuisisi Harmonie $01 \mathrm{~dB}$ dengan empat saluran masukan analog dan satu saluran keluaran digital yang dihubungkan ke komputer (Gambar 2). Analisis FFT dilakukan dari perangkat lunak $d B F A 32$ yang beroperasi dengan frekuensi sampel hingga $51,4 \mathrm{kHz}$ dan spektrum frekuensi hingga 3200 garis.

Prosedur pengambilan data dalam metode SASW mengikuti langkah-langkah eksperimen berikut ini.

1. Merencanakan jarak pengukuran antara sensor dan jarak titik sumber gelombang dengan sensor terdekatnya. Nilai jarak ini kemudian dilebarkan secara berganda, biasanya dimulai dengan jarak yang terpendek (Gambar 3). Dalam setiap konfigurasinya, jarak antara sensor pertama dan sumber gelombang ditentukan sama dengan jarak sensor pertama dan kedua. Perubahan jarak sensor ini bertujuan untuk memperoleh seluruh wilayah panjang gelombang yang dirancang dalam pengukuran.

2. Menentukan beberapa jenis dan dimensi sumber gelombang transien yang dipasangkan dengan pemilihan sensor yang sesuai untuk setiap wilayah frekuensi yang direncanakan. Nilai frekuensi yang dihasilkan oleh sesuatu sumber bergantung kepada bentuk dan berat sumber gelombang tersebut (Rosyidi, 2014).

3. Mengambil titik acuan sebagai titik tengah konfigurasi antar sensor. Seterusnya dua sensor dengan spesifikasi yang sama, diletakkan dalam satu garis lurus di atas permukaan lapisan yang telah diukur mengikut konfigurasi titik tengah sensor (Gambar 3). Sensor juga harus terlekat secara baik agar dapat mendeteksi pergerakan gelombang dengan jelas dan tidak terdapat gangguan pada perpindahan fase akibat reaksi yang berbeda dari sensor. Seterusnya penganalisis spektrum diatur untuk menunjukkan operasi spektrum tenaga, fungsi perpindahan atau spektrum tenaga silang dan fungsi koheren.

4. Menghasilkan energi gelombang yang berasal dari sumber transien di atas permukaan media. Setiap pengukuran gelombang, dilakukan perekaman berulang kali untuk memperoleh sinyal rata-rata dalam domain frekuensi. Rata-rata sinyal yang diperoleh melalui pengulangan pengukuran dapat menghilangkan pengaruh gangguan acak (random noise) dan sinyal yang tidak jelas pada proses perekaman data (Nazarian \& Stokoe, 1984).

5. Melakukan perhitungan kecepatan fase menggunakan beberapa nilai frekuensi spektrum fase. Pendekatan ini dilakukan untuk membandingkan kecepatan fase dari hasil penganalisis spektrum dengan nilai asumsi awal. Langkah ini dijalankan bagi mengontrol hasil spektrum fase dan nilai kecepatan supaya sesuai dengan media yang diukur.

6. Setelah pengukuran selesai, kedudukan sensor diubah sesuai dengan perencanaan jarak antar sensor pada langkah pertama. Selanjutnya, pengukuran diulangi sesuai langkah dua hingga enam di atas diulangi hingga seluruh konfigurasi sensor dalam pengujian dilakukan. 


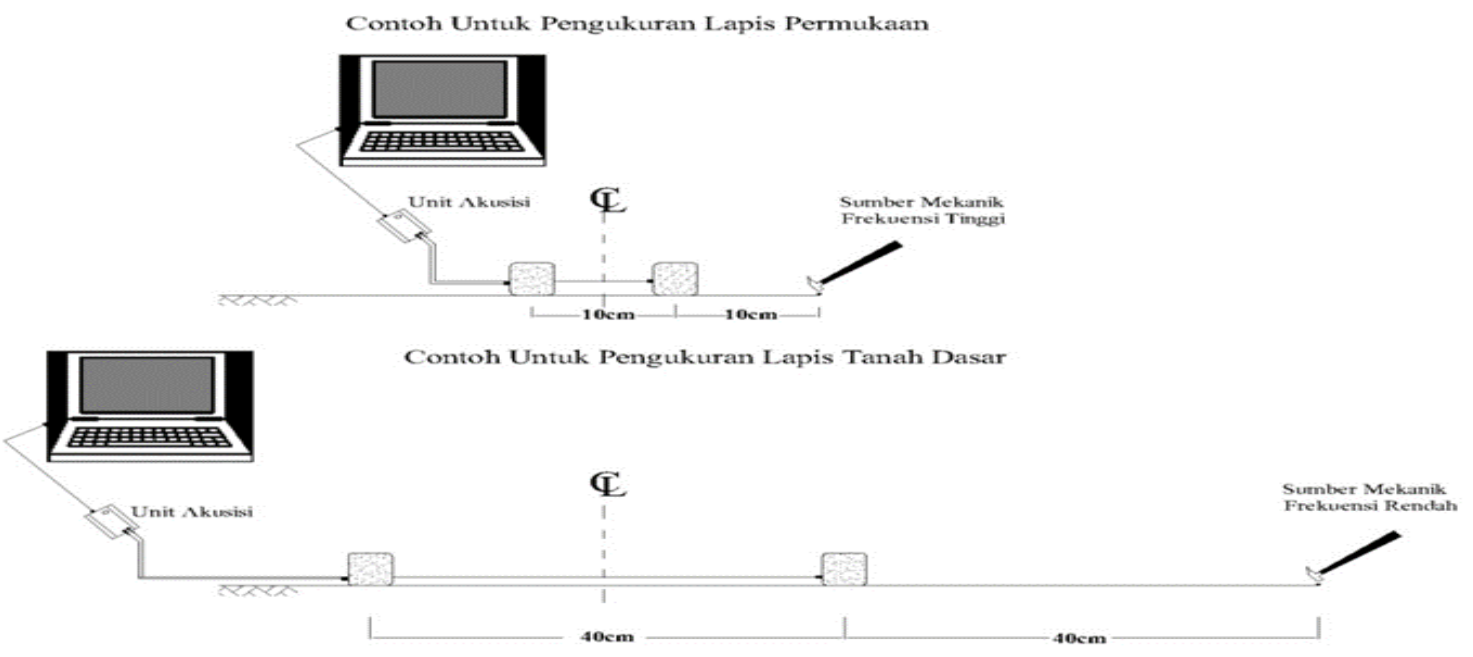

GAMBAR 3. Konfigurasi Titik Tengah Sensor Dalam Pengukuran

Dari data seismik yang diperoleh di lapangan, selanjutnya dilakukan tahapan analisis data menggunakan analisis FFT (Fast Fourier Transform). Algoritma Cooley-Tukey atau FFT (fast Fourier transform) menjadi dasar dalam transformasi digital dari sinyal gelombang berdomain waktu dan ditampilkan dalam spektrum berdomain frekuensi. Spektrum gelombang hasil FFT yang digunakan dalam analisis data SASW meliputi spektrum tenaga auto yang menggambarkan amplitudo atau energi gelombang setiap sinyal yang diterima, spektrum fungsi perpindahan yang menampilkan data beda fase antar sinyal dan spektrum fungsi koherensi yang menunjukkan keselarasan antar sinyal.

Selanjutnya dilakukan perhitungan kecepatan fase dan pembentukan kurva dispersi kecepatan fase menggunakan teknik beda fase. Teknik ini adalah salah satu pendekatan dalam menganalisis fungsi cepat rambat yang diturunkan dari pergerakan gelombang berbasis selisih data fase gelombang antar titik referensi.

Tahapan akhir dari analisis data SASW adalah proses inversi kurva dispersi gabungan. Dalam kajian ini, kurva dispersi gabungan disusun dengan algoritma rata-rata global (global average dispersion curve) sebagaimana dijelaskan dalam Rosyidi dkk. (2019). Asas pembentukan kurva dispersi dengan metode ini menggunakan konsep rerata bergerak (moving average) yang umum digunakan untuk memproses sinyal di bidang geofisik. Teknik rerata bergerak merupakan operasi linier yang digunakan untuk proses mendapatkan corak umum dalam pembuatan kurva.

Proses inversi kurva dispersi kecepatan fase menggunakan perangkat lunak program inversi WinSASW versi 3 dari Chung Ang University, Korea. Program memiliki tiga fungsi analisis yang dijalankan secara otomatis yaitu fungsi penyaringan atau juga dikenal sebagai fungsi penyamaran (masking), fungsi pembangunan kurva dispersi eksperimen kecepatan fase dan fungsi inversi. Proses inversi dalam penelitian ini menggunakan teori perambatan gelombang 3 D. Hasil akhir yang diperoleh merupakan profil kecepatan gelombang geser yang dianalisis berulang (iterasi) hingga mendapatkan nilai galat RMS (Root Mean Square, RMS) terendah menggunakan optimasi metode kemiripan maksimum (maximum likelihood method).

\section{Tahapan Analisis Hasil Pengujian}

Hasil penelitian ini disimpulkan setelah melalui proses validasi hasil akhir dilakukan. Hasil penelitian dipresentasikan secara kuantitatif dengan menampilkan nilai modulus elastisitas setiap material perkerasan jalan dari pengujian SASW. Korelasi empiris dilakukan dengan membandingkan hasil pengujian SASW dalam nilai CBR terhadap pengujian DCP (CBR lapangan) dan membandingkan dengan pengujian Marshall. 
Uji statistik deskriptif untuk menilai variabilitas kinerja struktural material perkerasan jalan diantaranya: nilai rata-rata, nilai tengah, koefisien korelasi, koefisien determinasi, simpangan baku, koefisien varian dan kesalahan baku.

\section{HASIL DAN PEMBAHASAN}

\section{Hasil Analisis Pavement Condition Index}

Dari hasil pengamatan di lapangan (visual observation) pada ruas jalan tersebut terdapat dua lapisan perkerasan yaitu perkerasan kaku dan perkerasan lentur, diberikan dalam Tabel 1. Pada perkerasan kaku dibagi pada nomor segmen 1 hingga 17, sedangkan pada perkerasan lentur pada no segmen 18 hingga 47. Sesuai dengan pengklasifikasian kondisi perkerasan menurut ASTM D6433-07, nilai PCI pada segmen 1 hingga 17 dikelompokkan pada kondisi perkerasan yang sangat baik (diberikan warna hijau pada Tabel 1). Untuk nomor segmen 18, 19, 20, 21, 22, 23, 24, 25, $26,27,28,29,31,36,37,39,47$ termasuk dalam kondisi gagal (warna merah), pada segmen 30, 32, 38, termasuk dalam kondisi kritis (warna merah); pada nomor segmen 33, 35, 40, 41 termasuk kondisi sangat buruk (warna merah); pada segmen 46 termasuk dalam kondisi buruk (warna merah); pada segmen 34, 45 termasuk kondisi sedang (warna kuning); segmen 42, 43, 44 dikelompokkan pada kondisi baik dan sangat baik (warna hijau). Dari keseluruhan segmen pengamatan pada lokasi penelitian di Jalan Langkap Tengklik, tersebut didapatkan nilai rata-rata PCI 49,76 yang termasuk dalam kondisi buruk. Kondisi buruk yang diperoleh dari analisis angka PCI dan kategori kondisi fungsional dari ASTM D6433-07 disebabkan karena kondisi perkerasan lentur yang tidak mampu menerima beban kendaraan diatasnya. Observasi di lapangan menunjukkan lalu lintas pada lokasi penelitian ini banyak didominasi oleh kendaraan berat (truk) pengangkut material pada jam-jam tertentu. Kendaraan berat dengan kecepatan rendah yang melebihi tonase ijin beban dapat mempercepat kerusakan perkerasan, terutama perkerasan lentur. Berbeda dengan perkerasan kaku dimana nilai
PCI yang diperolehi mencapai nilai 100 (maksimal) yang menunjukkan kategori sangat baik. Perkerasan kaku dengan nilai kekakuan yang tinggi dalam menerima beban berat, akan mendistribusikannya secara lebih merata ke lapisan fondasi atau tanah dasar di bawahnya. Hal ini berbeda dengan perkerasan lentur dimana sifat pembebanan perkerasan lentur yang lebih terpusat dan nilai tegangan yang disalurkan ke lapisan di bawahnya menjadi lebih besar. Dengan kata lain, kekakuan atau modulus elastisitas beton semen yang lebih besar pada perkerasan kaku dibandingkan dengan perkerasan lentur, maka beban yang disalurkan ke lapisan di bawahnya, menghasilkan tekanan yang lebih kecil, disebabkan makin luasnya area yang menampung beban tersebut, sehingga mampu dipikul oleh lapisan tanah dasar.Sebagai akibatnya, lendutan menjadi lebih kecil serta tegangan yang bekerja pada tanah dasar juga rendah.

\section{Hasil Pengujian DCP dan Konversi CBR-E}

Pengujian DCP dilaksanakan pada jalan di lokasi penelitian dengan kondisi segmen yang buruk dan sangat buruk yaitu pada segmen 18 hingga 47 yang terletak pada STA 0+900 hingga STA $1+250$. Hasil pengujian DCP dan konversi nilai CBR diberikan pada Gambar 4. Dari gambar tersebut dijelaskan sebaran nilai CBR dan modulus elastisitas yang diambil pada setiap STA di lokasi penelitian. Setiap titik pengujian DCP, secara umum diperoleh tiga lapisan yang dinyatakan dalam gambar sebagai Lapisan I, Lapisan II dan Lapisan III. Berdasarkan nilai indeks DCP (DCPI), dapat dikonversikan ke nilai modulus elastisitas (E) menggunakan persamaan (Rosyidi, 2004):

$E=537,76 \times D C P I^{-0,6645}$

Berdasarkan hasil pengujian dan sesuai dengan klasifikasi tanah terhadap nilai CBR dari Das (1993) didapati daya dukung tanah di lokasi penelitian dapat digolongkan pada kategori buruk hingga baik. Daya dukung tanah buruk sebagian besar ditemukan pada lapisan atas tanah dasar dengan nilai antara 3 hingga $7 \%$ (Das, 1993). Hal lain yang dapat dikaji dari hasil pengukuran daya dukung tanah ini adalah adanya variasi nilai daya dukung yang cukup 
besar dengan rentang nilai terendah $(3,17 \%)$ dan tertinggi $(41,47 \%)$ yang cukup lebar. Berkaitan dengan nilai modulus elastisitasnya, terlihat bahwa nilainya juga bervariasi antara 36,7 MPa hingga yang paling tinggi mencapai $168,89 \mathrm{MPa}$. Nilai modulus rendah ditemui pada STA $0+900$, STA $1+000$, STA $1+100$, dan STA1+200. Untuk STA $1+150$ dan STA $1+250$, ditunjukkan bahwa terdapat lapisan di bawah permukaan (lapisan II dan III) yang menunjukkan nilai lebih rendah dibandingkan lapisan I. Ini disebabkan oleh ketidaksamaan lapisan tanah dasar yang dimungkinkan terjadi karena pengaruh pemadatan yang berbeda atau lapisan permukaan tanah dasar sudah tercampur dengan material dari lapisan fondasi bawah sehingga nilainya relatif lebih besar dibandingkan tanah dasar di bawahnya.

TABEL 1. Hasil Pengamatan Visual dan Analisis PCI

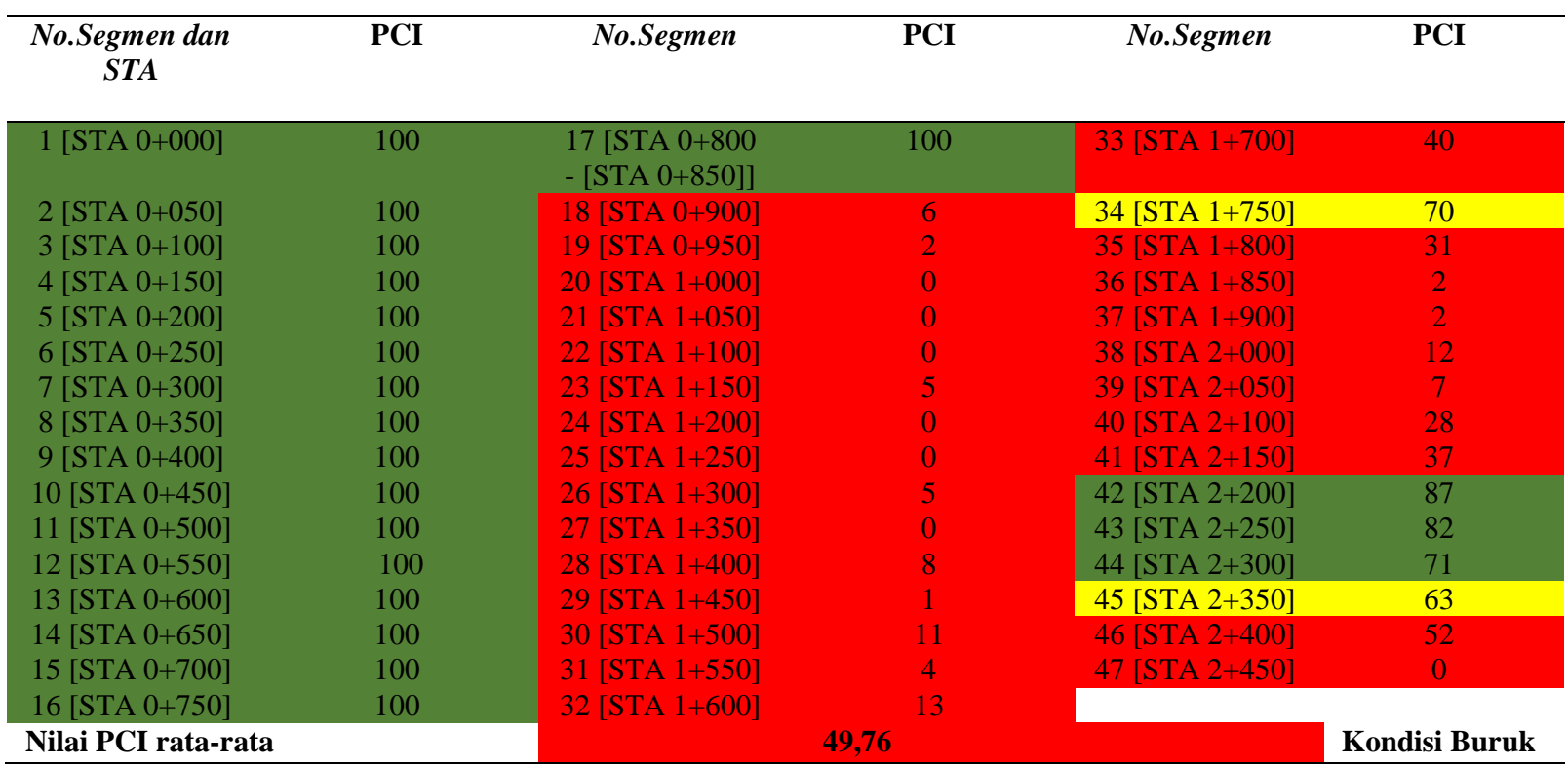

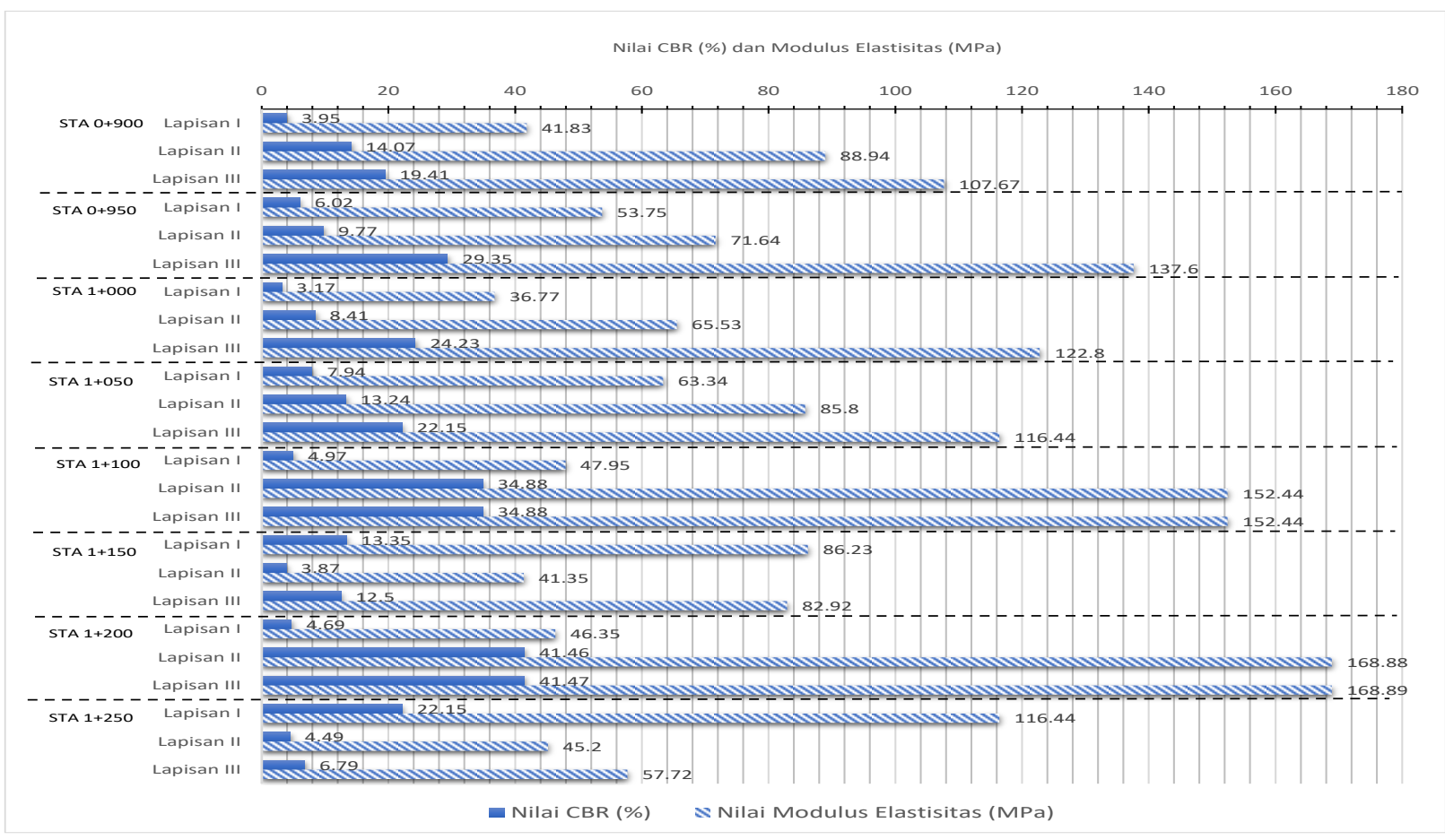

GAmbAR 4. Hasil Pengukuran Daya Dukung Tanah Dalam CBR dan Modulus Elastisitas Pada Beberapa Titik STA di Lokasi Penelitian Dari Hasil Pengujian DCP 
Hasil Pengujian Marshall

Pengujian Marshall dilakukan pada sampel lapisan permukaan untuk tipe perkerasan lentur setelah mengalami perendaman pada suhu $60^{\circ} \mathrm{C}$. Dari uji Marshall dihasilkan dua parameter kinerja bahan perkerasan jalan yaitu stabilitas dan kelelehan (deformasi) ditunjukkan pada Tabel 2. Parameter stabilitas Marshall selanjutnya menjadi dasar dalam penentuan modulus elastisitas perkiraan dari briket sampel campuran aspal yang diuji dengan persamaan empiris yang dihasilkan oleh Wiyono dkk (2012) dan dinyatakan berikut ini:

$$
E=\frac{4 P}{\Delta R v \cdot \pi \cdot t}(1+3 \mu)
$$

dimana,

$$
\begin{aligned}
E= & \text { modulus elastisitas }\left(\mathrm{N} / \mathrm{mm}^{2}\right) \\
\mu & =\text { nilai Poisson, } \\
P \quad= & \text { stabilitas Marshall }(\mathrm{N}) \\
\Delta R v= & \text { kelelehan atau deformasi horizontal } \\
& (\mathrm{mm}), \\
t \quad= & \text { diameter briket uji }(\mathrm{mm}) .
\end{aligned}
$$

Hasil nilai stabilitas Marshall dan modulus elastisitas menunjukkan kondisi perkerasan yang beragam atau bervariasi. Meskipun, nilai stabilitas tinggi, namun tidak menunjukkan kondisi yang sesuai dari hasil pengamatan nilai PCI karena ditemukan banyak kerusakan lapisan permukaan campuran aspalnya. Dengan demikian, rujukan penilaian kondisi kinerja struktural dari hasil pengujian Marshall saja tidak memiliki korelasi kuat terhadap penilaian kerusakan dan kondisi fungsional yang diamati.

\section{Hasil Pengujian SASW}

Pengukuran dengan metode SASW pada lokasi penelitian mendapatkan profil kekuatan bahan perkerasan jalan dalam parameter kecepatan gelombang geser dan nilai modulus elastisitasnya. Gambar 5 menunjukkan salah satu contoh profil kecepatan gelombang geser setiap lapisan perkerasan jalan yang meliputi lapisan permukaan, lapisan fondasi dan lapisan tanah dasar. Dari nilai kecepatan gelombang geser ini, menggunakan konsep elastik linier, dapat diperoleh nilai modulus elastisitasnya menggunakan persamaan sebagai berikut (Rosyidi, 2004):

$$
E=2 \frac{\gamma}{g} V_{s}^{2}(1+\mu)
$$

dengan,

$E \quad=$ modulus elastisitas $\left(\mathrm{kg} / \mathrm{m}^{2}\right)$,

$\mu=$ angka Poisson,

$\gamma=$ kepadatan bahan $\left(\mathrm{kg} / \mathrm{m}^{3}\right)$,

$\mathrm{g} \quad=$ percepatan gravitasi,

$V_{S} \quad=$ kecepatan gelombang geser $(\mathrm{m} / \mathrm{s})$.

Hasil pengukuran SASW untuk seluruh titik pengamatan diberikan pada Tabel 3.

Menurut kajian yang telah dilakukan Nazarian \& Stokoe (1984), ditunjukkan bahwa nilai modulus elastisitas untuk lapisan permukaan perkerasan jalan antara 1.400 hingga 7.700 $\mathrm{MPa}$, dapat dikategorikan sebagai nilai kekakuan yang baik. Dengan demikian, hasil modulus elastisitas dari pengukuran lapangan SASW pada lapisan aspal pada profil Jalan Langkap-Tengklik dapat dikelompokkan dalam nilai kekakuan jalan yang baik

TABel 2. Hasil Pengujian Marshall Berupa Nilai Stabilitas (kg) dan Korelasinya Terhadap Modulus Elastisitas (MPa) Untuk Lapisan Permukaan Aspal

\begin{tabular}{cccc}
\hline Sampel dari STA & Nilai Stabilitas $(\mathbf{k g})$ & $\begin{array}{c}\text { Nilai Kelelehan } \\
\text { (deformasi, } \mathbf{m m})\end{array}$ & $\begin{array}{c}\text { Modulus Elastisitas } \\
(\mathbf{M P a})\end{array}$ \\
\hline $\mathbf{0 + 9 0 0}$ & 1678,585 & 2,85 & 246,63 \\
$\mathbf{0 + 9 5 0}$ & 1694,088 & 3,90 & 285,61 \\
$\mathbf{1 + 0 0 0}$ & 1260,53 & 3,80 & 298,61 \\
$\mathbf{1 + 0 5 0}$ & 1248,287 & 3,90 & 189,04 \\
$\mathbf{1 + 1 0 0}$ & 1433,322 & 3,20 & 286,25 \\
$\mathbf{1 + 1 5 0}$ & 1276,023 & 3,70 & 119,03 \\
$\mathbf{1 + 2 0 0}$ & 1244,561 & 3,45 & 157,02 \\
$\mathbf{1 + 2 5 0}$ & 1421,766 & 3,74 & 254,16 \\
\hline
\end{tabular}



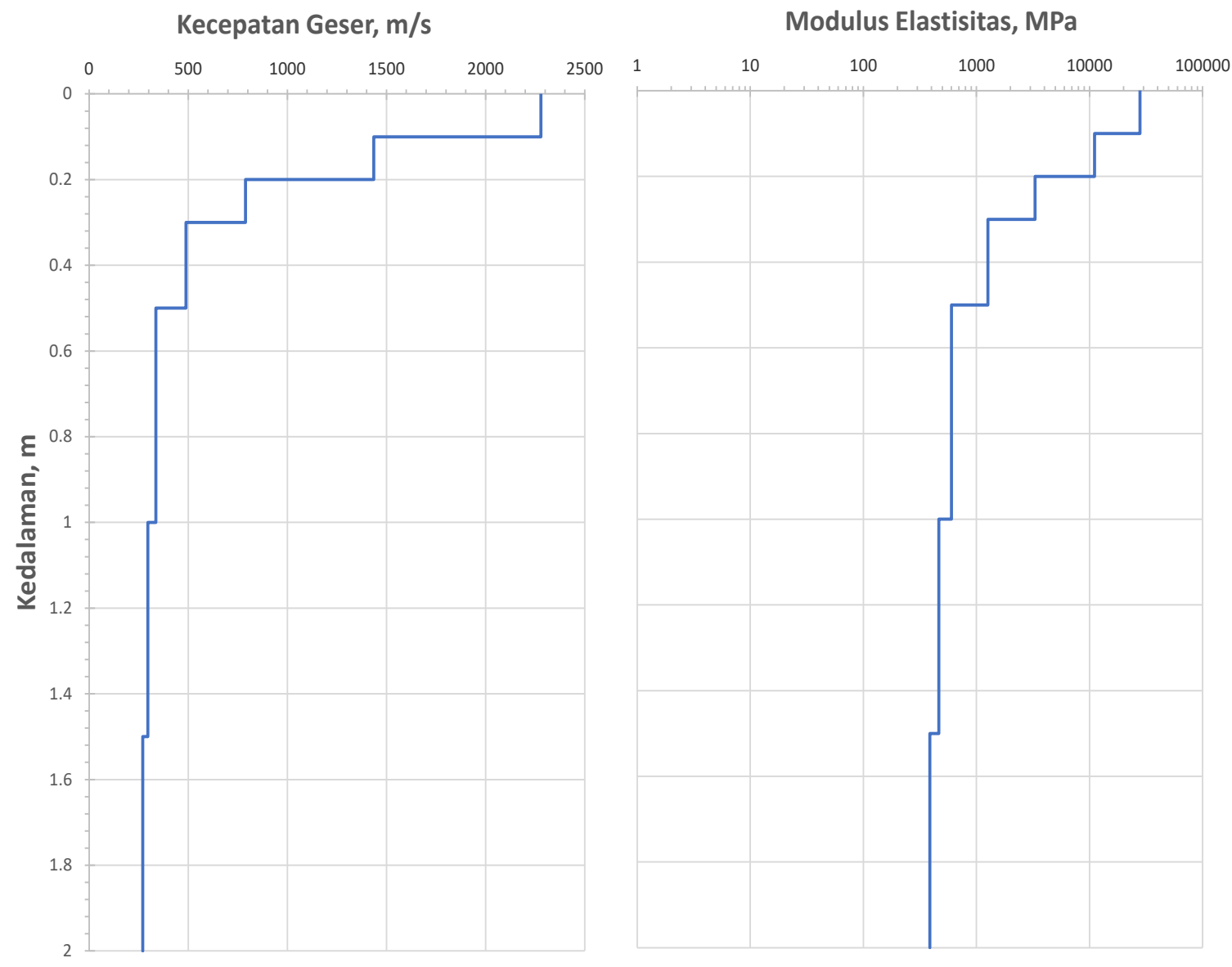

GAMBAR 5. Salah Satu Contoh Profil Hasil Pengujian SASW Berupa Nilai Kecepatan Gelombang Geser (m/s) dan Modulus Elastisitas (MPa) Pada STA 0+900 (Segmen 18)

Dari Tabel 3, hasil pengujian SASW menunjukkan nilai kecepatan gelombang geser yang bervariasi. Variabilitas ini menunjukkan kelemahan lapisan perkerasan jalan yang tidak dapat diidentifikasi dari hasil pengujian material laboratorium yang berasal dari pengujian beberapa titik-titik STA saja. Variabilitas kecepatan geser dan modulus elastisitas ditunjukkan dari ukuran koefisien varian pada masing-masing lapisan perkerasan jalan sebagaimana ditunjukkan dalam Tabel 4.

Koefisien varian (CV) merupakan alat ukur statistik untuk menjelaskan sebaran titik data pada sekelompok data di sekitar nilai rata-rata datanya. Nilai $\mathrm{CV}$ merupakan perbandingan antara simpangan baku terhadap nilai rerata datanya. Nilai CV dapat digunakan sebagai alat uji statistik yang efektif guna membandingkan tingkat variasi dari satu kelompok data terhadap kelompok data lainnya. Bahkan apabila terdapat nilai rata-rata berbeda satu sama lain, dapat dijelaskan besaran variasinya menggunakan koefisien ini. Dalam penelitian ini, koefisien varian yang dihasilkan dari pengujian SASW digunakan untuk menunjukkan sejauh mana variabilitas data dalam kaitannya dengan rata-rata populasi.

Lapisan permukaan perkerasan jalan memiliki nilai koefisien varian $29,78 \%$, hal ini menunjukkan simpangan nilai yang cukup besar dari nilai reratanya yaitu $1336 \mathrm{~m} / \mathrm{s}$. Demikian juga hal sama didapati untuk lapisan tanah dasar dengan nilai CV sebesar 33,37\%. Kedua lapisan dapat dikenali memiliki variabilitas yang cukup besar secara lateral dan kondisi ini yang menyebabkan ketidakseragaman mutu lapisan yang berpengaruh kepada kualitas fungsional jalan yang ditunjukkan adanya kerusakan-kerusakan permukaan jalan dari nilai PCI yang telah diukur (Tabel 1). 
TABEL 3. Hasil Pengujian SASW Dalam Kecepatan Geser (m/s) dan Modulus Elastisitas (MPa) Pada Perkerasan Lentur di Lokasi Penelitian

\begin{tabular}{|c|c|c|c|c|c|c|c|c|c|}
\hline \multirow{2}{*}{$\begin{array}{l}\text { 1. LAPISAN } \\
\text { PERMUKAAN: } \\
\text { Rerata } V_{\mathrm{S}}(\mathrm{m} / \mathrm{s})\end{array}$} & STA 1 & STA 2 & \multicolumn{2}{|l|}{ STA 3} & STA 4 & STA 5 & STA 6 & STA 7 & STA 8 \\
\hline & 1812,73 & 1465,32 & \multicolumn{2}{|l|}{1294,66} & 1571,67 & 1579,18 & 1426,66 & 1399,03 & 1287,88 \\
\hline Rerata E (MPa) & 17686,09 & 11556,65 & \multicolumn{2}{|l|}{9021,54} & 13295,03 & 13422,40 & 10954,91 & 10534,63 & 8927,34 \\
\hline \multicolumn{10}{|l|}{$\begin{array}{l}\text { 2. LAPISAN } \\
\text { FONDASI: }\end{array}$} \\
\hline Rerata $\mathrm{V}_{\mathrm{S}}(\mathrm{m} / \mathrm{s})$ & 492,19 & 497,15 & \multicolumn{2}{|l|}{493,03} & 491,37 & 489,71 & 488,46 & 481,81 & 490,15 \\
\hline Rerata E (MPa) & 1313,73 & 1340,38 & \multicolumn{2}{|l|}{1318,24} & 1309,39 & 1300,57 & 1293,92 & 1258,94 & 1302,87 \\
\hline \multicolumn{10}{|l|}{$\begin{array}{l}\text { 3. LAPISAN } \\
\text { TANAH } \\
\text { DASAR: }\end{array}$} \\
\hline Rerata $\mathrm{V}_{\mathrm{S}}(\mathrm{m} / \mathrm{s})$ & 280,67 & 293,31 & \multicolumn{2}{|l|}{267,15} & 354,01 & 281,32 & 351,29 & \multirow{2}{*}{$\begin{array}{l}349,74 \\
630,17\end{array}$} & \multirow{2}{*}{$\begin{array}{l}333,16 \\
571,83\end{array}$} \\
\hline Rerata E (MPa) & 405,85 & 443,23 & 367,70 & & 67 & 407,73 & 635,77 & & \\
\hline $\begin{array}{l}\text { 1. LAPISAN } \\
\text { PERMUKAAN: }\end{array}$ & STA 9 & STA 10 & STA 11 & STA 12 & STA 13 & STA 14 & STA 15 & STA 16 & STA 17 \\
\hline Rerata Vs (m/s) & 1285,72 & 1169,52 & 1284,66 & 1260,38 & 1456,26 & 1541,80 & 1266,29 & 1358,18 & 1402,30 \\
\hline Rerata E (MPa) & 8897,40 & 7361,75 & 8882,74 & 8550,09 & 11414,21 & 12794,43 & 8630,51 & 9928,54 & 10583,92 \\
\hline \multicolumn{10}{|l|}{$\begin{array}{l}\text { 2. LAPISAN } \\
\text { FONDASI: }\end{array}$} \\
\hline Rerata Vs (m/s) & 501,96 & 507,99 & 492,04 & 469,11 & 452,14 & 424,12 & 456,64 & 480,45 & 519,21 \\
\hline Rerata E (MPa) & 1366,46 & 1399,47 & 1312,94 & 1193,44 & 1108,66 & 975,52 & 1130,82 & 1251,83 & 1461,94 \\
\hline \multicolumn{10}{|l|}{$\begin{array}{l}\text { 3. LAPISAN } \\
\text { TANAH } \\
\text { DASAR: }\end{array}$} \\
\hline Rerata Vs (m/s) & 313,10 & 235,96 & 349,34 & 273,08 & 312,88 & 168,46 & 164,97 & 244,71 & 298,37 \\
\hline Rerata E (MPa) & 505,078 & 286,84 & 628,74 & 384,20 & 504,34 & 146,21 & 140,22 & 308,51 & 458,65 \\
\hline
\end{tabular}

TABEL 4. Analisis Statistik Deskriptif Untuk Menentukan Variabilitas Dari Pengujian SASW

\begin{tabular}{cccc}
\hline & Lapisan Permukaan & Lapisan Fondasi & Lapisan Tanah Dasar \\
\hline simpangan baku (m/s) & 397,86 & 114,90 & 87,28 \\
maksimum (m/s) & 1991,84 & 697,95 & 444,20 \\
minimum (m/s) & 623,12 & 244,49 & 126,96 \\
rerata (m/s) & 1336,12 & 501,96 & 262,32 \\
CV - koefisien varian & $29,78 \%$ & $22,89 \%$ & $33,27 \%$ \\
\hline
\end{tabular}

Adapun untuk lapisan fondasi, nilai CV yang diperolehnya lebih rendah yaitu $22,89 \%$ yang menunjukkan keseragaman kualitas bahan yang lebih baik dibandingkan lapisan permukan dan tanah dasarnya.Teknik tomografi dari Rosyidi (2015), digunakan dalam analisis ini untuk menampilkan data kecepatan geser dari pengukuran SASW dalam model 3-D profil perkerasan jalan (Gambar 6) dan detail penampang 2-D untuk mengidentifikasi variabilitas pada lapisan permukaan jalan (Gambar 7). Meskipun secara tren umum, perubahan nilai kecepatan gelombang beraturan yang menunjukkan perubahan kekakuan yang semakin lebih kecil dari lapisan permukaan ke lapisan tanah dasar, namun, hasil analisis 3-D juga menunjukkan adanya perbedaan spektrum warna yang cukup jelas pada permukaan jalan. Warna spektrum terang (merah) mengindikasikan nilai kekakuan yang tinggi dan warna spektrum ke gelap (biru tua) yang rendah.

Gambar 7, secara lebih jelas, menunjukkan variabilitas di lapisan permukaan. Sebagaimana profil 3-D (Gambar 4) sebelum ini, penampang memanjang 2-D juga menunjukkan adanya variabilitas pada kekakuan material lapisan permukaan dan perbedaan ketebalan lapisan. Setidak-tidaknya, 
diidentifikasi ada empat (4) anomali lapisan di permukaan jalan yang ditandai dengan kotak dengan angka romawi I, IV, VI, VIII. Lokasi tersebut berada pada segmen 18 hingga 30 dari pengamatan PCI yang menunjukkan kondisi jalan yang buruk hingga gagal. Secara visual didapati gangguan fungsional perkerasan jalan (pavement distress) yang ditandai dengan keretakan permukaan di sekitar anomali. Anomali lain ditemukan dari nilai variabilitas kecepatan geser yang rendah diantara nilai yang seharusnya, yaitu ditemui pada daerah yang diberikan tanda kotak II, III, V, VII dan XI. Anomali tersebut dimungkinkan karena perbedaan tebal lapisan permukaan perkerasan atau bahkan telah terjadi lapisan lebih (weak layer) yang diakibatkan rendahnya mutu pelaksanaan pekerjaan. Anomali tersebut bisa menyebabkan turunnya lapisan permukaan atau alur pada jejak roda (rutting) hingga dapat menyebabkan lubang jalan (potholes) yang diidentifikasi dalam penilaian PCI (Tabel 1). Meskipun demikian, nilai kekakuan lapisan permukaan perkerasan ini tidak memiliki korelasi kuat untuk membuktikan bahwa kinerja struktural berpengaruh terhadap kinerja fungsional dan sebaliknya. Hal ini ditunjukkan dengan nilai kekakuan material lapisan perkerasan masih dikelompokkan dalam nilai modulus elastisitas yang baik. Kondisi ini juga sama seperti dikemukakan dalam kajian yang dilakukan oleh Barudin, dkk (2019). Kajiannya dilakukan dengan mengumpulkan 1198 jumlah data kinerja fungsional dengan International Roughness Index (IRI), kedalaman alur, dan kedalaman tekstur, sedangkan untuk sifat struktur dilakukan dengan pengukuran modulus elastisitas menggunakan peralatan uji DCP dan Falling Weight Deflectometer (FWD). Hasil ini secara umum menyimpulkan bahwa tidak ada korelasi antara sifat fungsional dan sifat struktural pada perkerasan lentur. Menurunnya kinerja fungsional dalam kajian ini diamati disebabkan oleh berkurangnya fungsi permukaan yang salah satunya diidentifikasi melalui anomali pada lapisan perkerasan, berupa variabilitas nilai kekakuan sebagaimana dijelaskan dalam Gambar 7. Variabilitas ini menyebabkan respon material dalam menerima beban menjadi berbeda dan dapat menjadi pencetus adanya kerusakan permukaan (surface distress), selain tentunya faktor lingkungan dan drainase juga berkontribusi yang besar dalam kinerja fungsional perkerasan jalan (Trimukti, 2009; Munggarani \& Wibowo, 2017).

Perbandingan Hasil Pengukuran SASW dengan Penelitian Sebelumnya untuk Lapisan Fondasi dan Tanah Dasar

Untuk memvalidasi nilai-nilai kekakuan material dari hasil pengukuran SASW selanjutnya dilakukan perbandingan dengan kajian-kajian sejenis menggunakan metode seismik yang dilakukan pada perkerasan lentur. Tabel 5 hingga 7 menunjukkan perbandingan nilai kecepatan gelombang geser dan hasil analisis modulus elastisitasnya pada setiap lapisan fondasi dan lapisan subgrade atau tanah dasar perkerasan jalan dengan kajiankajian sebelumnya. Dari hasil perbandingan ini, dapat disimpulkan bahwa nilai kekakuan material pada lapisan fondasi ditunjukkan nilai yang relatif sama dan demikian juga untuk lapisan tanah dasar juga masuk dalam kriteria nilai modulus tanah dasar yang sesuai dan rasional.

\section{Perbandingan Hasil Pengukuran SASW dengan Pengujian Marshall dan DCP}

Dalam penelitian diperoleh nilai yang berbeda pada nilai modulus elastisitas antara pengujian Marshall, DCP dan SASW. Perbedaan itu karena terjadi perbedaan nilai regangan modulus elastisitas dari ketiga pengujian tersebut. Hasil SASW lebih tinggi karena nilai regangan digolongkan dalam nilai yang sangat kecil, $<0,001 \%$, sehingga nilai modulus relatif konstan. Adapun, untuk modulus elastisitas yang dihasilkan dari pengujian Marshall dan DCP, nilai regangan lebih besar dan nilai modulus dipengaruhi oleh besarnya regangan. Selain itu, benda uji Marshall sebelum dilakukan pengujian direndam dalam air hangat dengan suhu $60^{\circ} \mathrm{C}$ sampai 30 menit sehingga menjadikan benda uji dalam kondisi sangat kritis. Dalam kondisi sangat kritis tersebut berpengaruh pada nilai modulus elastisitas prediksi dari pengujian Marshall menjadi kecil. 


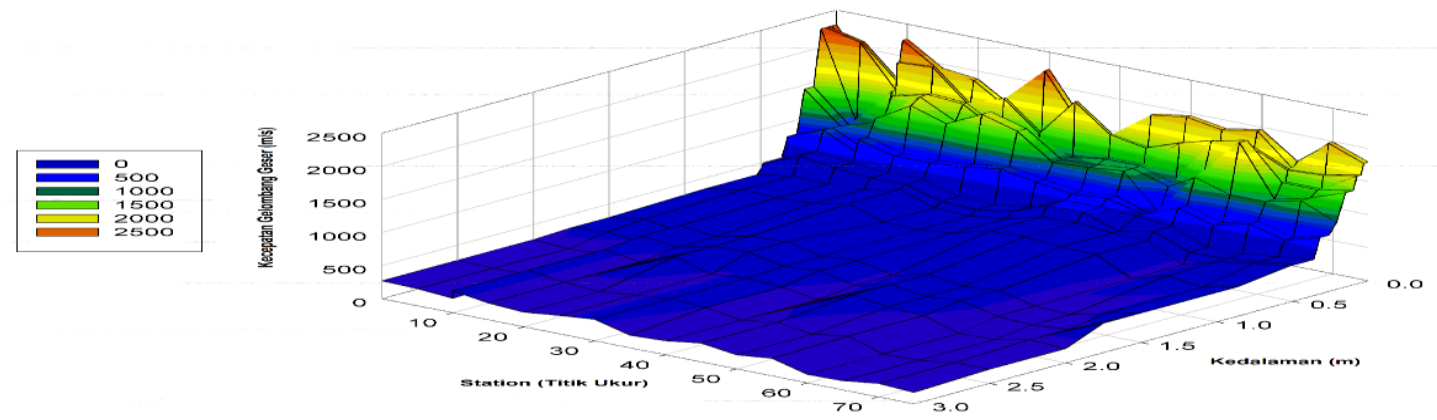

Gambar 6. Profil 3-D Kecepatan Gelombang Geser yang Menunjukkan Variabilitas Perkerasan Jalan

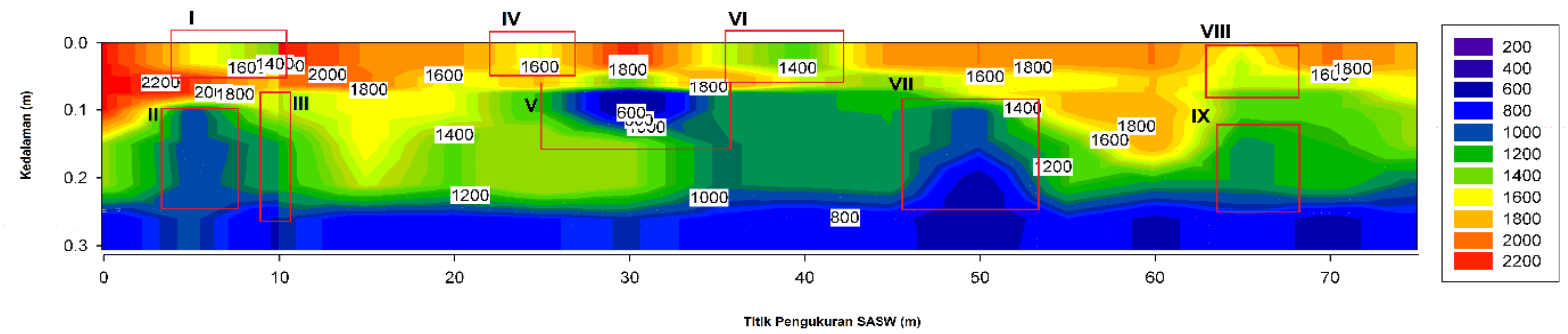

GAMBAR 7. Profil 2-D Kecepatan Gelombang Geser yang Menunjukkan Variabilitas Perkerasan Jalan

TABEL 5. Perbandingan Hasil Kecepatan Gelombang Geser Dengan Peneliti Sebelumnya Pada Lapisan Fondasi

\begin{tabular}{cc}
\hline Sumber Kajian & Kecepatan Gelombang Geser \\
\hline Kajian ini & $244,49-697,95 \mathrm{~m} / \mathrm{s}$ \\
Rosyidi \& Taha (2004) & $100-290 \mathrm{~m} / \mathrm{s}$ \\
Nazarian \& Stokoe (1984) & $174-300 \mathrm{~m} / \mathrm{s}$ \\
Al-Hunaidi (1998) & $100-500 \mathrm{~m} / \mathrm{s}$ \\
\hline
\end{tabular}

TABel 6. Perbandingan Hasil Modulus Elastisitas Dengan Peneliti Sebelumnya Pada Lapisan Fondasi

\begin{tabular}{ll}
\hline \multicolumn{1}{c}{ Sumber Kajian } & \multicolumn{1}{c}{ Modulus Elastisitas } \\
\hline Kajian ini & $324,16-2641,75 \mathrm{MPa}$ \\
Rosyidi \& Taha (2004) & $4.10^{6}-1,1.10^{7} \mathrm{~kg} / \mathrm{m}^{2}$ \\
Nazarian \& Stokoe (1984) & $210-6741$ (crushed limestone) $\mathrm{MPa}$ \\
& 8763 (crushed limestone $+2 \%$ lime) $\mathrm{MPa}$ \\
\hline
\end{tabular}

TABEL 7. Perbandingan Hasil Kecepatan Gelombang Geser Pada Lapisan Tanah Dasar Dengan Penelitian Sebelumnya

\begin{tabular}{lcc}
\hline \multicolumn{1}{c}{ Sumber Kajian } & Jenis Tanah & Kecepatan gelombang geser \\
\hline Kajian ini & N/A & $126,96-444,20 \mathrm{~m} / \mathrm{s}$ \\
Rosyidi (2004) & N/A & $134,43-171,75 \mathrm{~m} / \mathrm{s}$ \\
Das (1993) & Pasir baik & $30,50-152,40 \mathrm{~m} / \mathrm{s}$ \\
& Pasir padat & $228,60 \mathrm{~m} / \mathrm{s}$ \\
& Kerikil & $182,88-228,60 \mathrm{~m} / \mathrm{s}$ \\
Nazarian \& Stokoe (1984) & Lempung basah & $152,40 \mathrm{~m} / \mathrm{s}$ \\
& Pasir lepas Pasir padat & $147,50-211,90 \mathrm{~m} / \mathrm{s}$ \\
& & $277,90-282,90 \mathrm{~m} / \mathrm{s}$ \\
\hline
\end{tabular}




\section{KESIMPULAN}

Penelitian ini menjelaskan penilaian dan evaluasi bahan perkerasan jalan berbasis pengujian lapangan seismik menggunakan metode spectral analysis of surface wave (SASW). Metode SASW ini juga digunakan untuk mengidentifikasi dan menentukan variabilitas atau keragaman kinerja struktur perkerasan jalan dengan baik dan akurat. Nilai kinerja struktural jalan diamati adalah kecepatan gelombang geser (Vs) dan modulus elastisitas (E). Nilai yang diperolehi dari kedua parameter kinerja struktural perkerasan tersebut menunjukkan nilai yang baik dimana perkerasan dapat dikategorikan memiliki kekakuan yang baik. Meskipun demikian, diidentifikasi dari hasil pengukuran SASW, terdapat variabilitas kekakuan yang menyebabkan adanya anomali pada permukaan perkerasan dan pada lapisan permukaan permukaan. Anomali ini yang diidentifikasi menyebabkan perlemahan pada perkerasan jalan. Hasil penilaian PCI menguatkan analisis ini dimana ditemui kondisi jalan yang buruk hingga gagal pada lokasi yang berdekatan. Meskipun demikian, dari penelitian ini tidak dijumpai adanya ada korelasi kuat yang mengaitkan antara kinerja fungsional dan struktural pada perkerasan lentur. Penelitian lanjutan untuk mengukur keterkaitan kedua kinerja ini dapat diteruskan sebagai rekomendasi lanjutan.

\section{UCAPAN TERIMA KASIH}

Penulis dapat menyampaikan penghargaan dan terima kasih kepada asisten laboratorium kepada Ardiyanto Nugroho dan Muhammad Fikri Priadi. Penulis juga mengucapkan terima kasih kepada Program Studi Sarjana Teknik Sipil UMY dan LP3M UMY yang telah memberikan kemudahan dan fasilitas untuk menjalankan penelitian ini.

\section{DAFTAR PUSTAKA}

AASHTO T-245-74. Worksheet for A Marshall Mix Design. The American Association of State Highway and Transportation Officials (AASHTO), Standard Specification for Transportation Materials, and Methods of Sampling and Testing.

Al-Hunaidi, M. O. (1998). Evaluation-based genetic algorithms for analysis of nondestructive surface waves test on pavements, NDT \&E International, 31(4), 273-280. https://doi.org/10.1016/S09638695(98)00007-3

Babashamsi, P., Yusoff, N. I. M., Ceylan, H., Md Nor, N., \& Jenatabadi, H. (2016). Sustainable development factors in pavement life-cycle: Highway/airport review. Sustainability, 8(3), 248. https://doi.org/10.3390/su8030248

Barudin, N. M., Yaacob, H., Hassan, N. A., Warid, M. N. M., Idham, M. K., Ismail, C. R., Nor, H. M., Hainin, M. R., Mohamad, A., Afiqah, R. N., Ayob, M. F., \& Jaya, R. P. (2019). Correlation between functional and structural properties of flexible pavement. IOP Conference Series: Earth and Environmental Science 220, 012007.

Carvalho, A. F. C., \& Santos, L. G. D. P. (2019). Maintenance of airport pavements: The use of visual inspection and IRI in the definition of degradation trends. International Journal of Pavement Engineering, 20(4), 425-431. https://doi.org/10.1080/10298436.2017.1 309189

Das, B. M. (1993). Mekanika tanah (Prinsipprinsip rekayasa geoteknik) Jilid 1 , Erlangga, Jakarta.

Di Mascio, P., \& Moretti, L. (2019). Implementation of a pavement management system for maintenance and rehabilitation of airport surfaces. Case Studies in Construction Materials, 11. https://doi.org/10.1016/j.cscm.2019.e002 51 
Munggarani, N. A., \& Wibowo, A. (2017). Kajian faktor-faktor penyebab kerusakan dini perkerasan jalan lentur dan pengaruhnya terhadap biaya penanganan. Jurnal Infrastruktur, 3(1), 1-9.

Nazarian, S. \& Stokoe II, K. H. (1984). In-situ shear wave velocity from spectral analysis of surface waves. Proc.of 8th World Conf. on Earthquake Engineering 3, 31-38.

Rosyidi, S. A. P. (2004). Evaluation of dynamic stiffness of pavement material using SASW method. Master Thesis. Universiti Kebangsaan Malaysia.

Rosyidi, S. A. P. (2015). Simultaneous in-situ stiffness and anomalies measurement on pavement subgrade using tomography surface waves technique. Procedia Engineering, $125,534-540$. https://doi.org/10.1016/j.proeng.2015.11. 057

Rosyidi, S. A. P., \& Taha, M. R. (2004). Measurement of pavement moduli using simple surface wave propagation technique. Proceeding of the $7^{\text {nd }}$ Symposium of Forum Studi Transportasi antar Perguruan Tinggi (FSTPT). Catholic Parahyangan University. 11 September 2004.

Rosyidi, S. A. P., \& Yusoff, N. I. M. (2018). Wavelet-spectrogram analysis of surface wave technique for in situ pavement stiffness measurement, Journal of Materials in Civil Engineering, 30(11). https://doi.org/10.1061/(ASCE)MT.1943 $-5533.0002504$

Rosyidi, S. A. P., Yusoff, N. I. M., Ismail, N. N., \& Mat Yazid, M. R. (2021). Integrated time-frequency wavelet analysis and impulse response filtering on SASW test for rigid pavement stiffness prediction, Ain Shams Engineering Journal, 12(1), 367-380. https://doi.org/10.1016/j.asej.2020.05.00 6

SNI 06-2489-1991. Metode pengujian campuran aspal dengan alat Marshall. Departemen Pekerjaan Umum.
Surat Edaran Menteri Pekerjaan Umum No. 04/SE/M/2010 tentang Pemberlakukan Pedoman Cara Uji California Bearing Ratio (CBR) dengan Dynamic Cone Penetrometer (DCP). Kementerian Pekerjaan Umum.

Trimukti, E. (2009). Tinjauan kerusakan jalan provinsi pada ruas Nanga Pinoh - Sokan Kabupaten Melawi. Jurnal Teknik Sipil, 9(1), 125-138. http://dx.doi.org/10.26418/jtsft.v9i1.286

Vancura, M. E. (2013). Evaluation of in-situ variability of concrete pavement characteristics and their effect on performance. Ph.D. Dissertation. University of Minnesota, USA.

Wiyono, A. W. W., Setiawan, A., \& Nurhidayat, N. (2012). Pengaruh suhu terhadap modulus elastisitas dan angka poisson beton aspal lapis aus (AC-WC) dengan kapur sebagai filler. Jurnal Rekayasa dan Manajemen Transportasi, 2(2), $105-114$.

PENULIS:

Sri Atmaja P. Rosyidi

Program Studi Teknik Sipil, Fakultas Teknik, Universitas Muhammadiyah Yogyakarta. Jalan Brawijaya, Tamantirto, Kasihan, Bantul.

Email: atmaja_sri@umy.ac.id 